\title{
FROM CRISIS TO SPECIALTY COFFEE The Case of Nicaraguan Smallholder Cooperatives and Jesuit Business Education for Sustainability and Justice
}

\author{
QUAN LE (corresponding author) \\ Department of Economics, Albers School of Business and Economics \\ Seattle University, Seattle, WA, U.S.A. \\ lequ@seattleu.edu
}

GRACE JOVANOVIC (undergraduate student)

International Business and Environmental Studies

Seattle University, Seattle, WA, U.S.A.

jovanov2@seattleu.edu

\begin{abstract}
Project-based service-learning has been proven to be an effective experiential learning opportunity that complements standard curricula in business schools. Seattle University (SU) has collaborated with its sister university, Universidad de Centro Americana (UCA) in Managua, Nicaragua, since 2015 on several project-based service-learning experiences focused on sustainable coffee farming practices and the implications that climate change may have on coffee farms and communities. This partnership with UCA and coffee cooperatives has its roots in the global coffee crisis of the early 2000s and has produced multiple projects that support farmers entering the specialty coffee markets. This paper as such presents the outcomes of our annual field research that took place in Penãs Blancas, Nicaragua in March 2018. Using the framework of sustainable coffee in light of environmental, social, and economic sustainability objectives, we provide evidence that many farmers in Nicaragua have been experiencing issues with their farms' sustainability. Our findings, moreover, reveal that the direct trade model used by the SU student-run social enterprise Café Ambiental is the most effective means of ensuring the farmers' economic sustainability, thereby allowing them to develop the environmental sustainability of their farms as well as improve their family and community health, education, and overall livelihoods for enhanced social sustainability. This social enterprise model created by SU students takes significant steps toward fulfilling the needs and improving the lives of coffee farmers in Nicaragua while preserving the land at the same time so future generations can grow quality coffee. Finally, we believe that our project has potential that is transferable to other Jesuit higher education institutions that utilize and pursue similar structures and objectives.
\end{abstract}




\section{KEYWORDS}

sustainable coffee; cooperatives; Jesuit business education; Seattle University;

Universidad de Centro Americana; Nicaragua

\section{INTRODUCTION}

Jesuit business schools have identified service-learning as one of the five pillars of Jesuit education along with ethics and professional responsibility, personal identity, social justice, and faith and spirituality (Spitzer, 2010). Indeed, projectbased service-learning has been proven to be an effective experiential learning tool that complements standard curricula in business schools. It is possible, therefore, for Jesuit universities with a common mission and a long history of true partnership to work together for the promotion of social justice through service-learning projects, especially given the large network of Jesuit higher education institutions across the globe. The scope of these experiential opportunities, however, is often restricted to local projects due to limited access to resources that are essential for international efforts. This paper thus aims to document the outcomes of a project-based servicelearning trip which could serve as a model of experiential learning for students at Jesuit higher education institutions around the world. The project, a recent international collaboration between Seattle University (SU) in the United States and its sister university, Universidad de Centro Americana in Nicaragua (UCA), demonstrates the commitment of Jesuit universities to develop leaders for a just and humane world, particularly through service for those on the margins while enriching opportunities for the education of the whole person.

Since the global coffee crisis of 2001-2003, faculty and students at SU and UCA have been collaborating to apply their expertise in service of the Jesuit mission. Multiple initiatives have been developed over the years, such as a chemistry-based project that developed a basic science of coffee fermentation kit to assist farmers in determining the optimal fermentation of their farms, an engineering project that developed coffee wastewater treatment facilities for small farms, and a couple of economic studies on fair trade, global coffee supply chain management, and sustainable coffee (Le, Wild, \& Jackels, 2017). 
In his encyclical Laudato Si', Pope Francis expressed his concern that climate change is a global problem with grave implications: environmental,
social, economic, political and for the distribution of goods ... many of the
poor live in areas particularly affected by phenomena related to warming,
and their means of subsistence are largely dependent on natural reserves
and ecosystemic services such as agriculture, fishing and forestry.
(Francis, 2015: \#25)

The Pope strongly emphasized a need for collaborations to protect the environment among all groups. In response therefore to the encyclical, our annual project-based service-learning trip in 2018, organized by SU and UCA, focused on sustainable coffee farming practices in Nicaragua and on the challenges climate change presents to those practices. The primary objective of this project was to foster a partnership with colleagues at UCA and with cooperatives to assess the needs of Nicaraguan coffee farmer communities while also providing educational opportunities for students at SU and UCA through an experiential learning project.

The framework of sustainable coffee has three main objectives: environmental sustainability, which represents the eco-environment; social sustainability, referring to when the production system maintains respect for social principles; and economic sustainability, which pertains to the financial viability of the activity. Sustainable coffee farming practices in this context preserve the capacity of future generations of farmers to continue producing high quality coffee. Thus, accompanied by five faculty members and students from UCA, seven faculty members and students from SU (including the authors of this paper) traveled to Penãs Blancas, the coffee producing region of Nicaragua, for ten days in March 2018. Their research focused on analyzing the current sustainability of coffee farms and the issues farmers have been facing under the threat of climate change.

\section{CAFÉ AMBIENTAL: A STUDENT-LED SOCIAL ENTERPRISE AND BUSINESS EDUCATION OPPORTUNITY AT SEATTLE UNIVERSITY}

A group of business faculty and students from SU traveled to Nicaragua in 2015 with chemistry professor Susan Jackels and students and faculty from the engineering school to build a coffee wastewater treatment facility for a small cooperative farmer. While on the trip, the business team conducted an economic analysis of fair trade coffee. Their farm visits, surveys, and literature reviews revealed 
that coffee farmers were receiving the least of the profits despite being the backbone of the coffee industry (Le et al., 2017). At the end of the trip, a first batch of coffee was purchased directly from the farmers who belonged to a cooperative that had assisted in the study (using a small amount of money that was left over from the grant of the Office of Global Engagement).

That purchase was the first step for what would later become the social enterprise Café Ambiental, SPC, which was established after the field research in Nicaragua exposed drastic inequities across the coffee value chain. The mission was simple: empower coffee farmers by providing fair and sustainable wages for the coffee they produce. The vertically integrated supply chain cut out the middlemen and guaranteed the largest percentage of profit possible for the farmers. Collaboration with students and faculty from UCA for remaining in contact with and supporting the farmers and their cooperatives ensured that operations were running efficiently.

Café Ambiental has been working directly with farmers in Nicaragua since 2015. Business students and faculty at SU have already gone on three annual field trips so far to Nicaragua to study the country's coffee industry and purchased four micro-lots to date of specialty grade coffee beans directly from the farmers. The business model centers on the economic empowerment of the farmers as it provides them with $65 \%$ of revenues. To date, over $\$ 30,000$ in annual revenues have been generated from business to business and business to consumer sales on campus and in the greater Seattle community under the brand MotMot Coffee, named after the national bird of Nicaragua. The project has also provided support in various ways: in the academic year (AY) 2015-2016, proceeds from the business were used to purchase school supplies to support the education of farmers' children; in AY 2016-2017, the organization addressed transportation issues and funded bus transit to ensure that students were able to attend school, thereby improving attendance rates; finally, in AY 2017-2018, the organization supported, in solidarity with UCA, those students and their families who were impacted by the political turmoil in Nicaragua.

Café Ambiental was a key component in SU becoming the first Fairtrade University in the Pacific Northwest. It continues its operations today in the Albers School of Business and Economics as a student-created and student-run coffee business, selling fair trade organic coffee in the Seattle area and sending profits back to the farmers. The Café has grown yearly, starting out with a few students all the 
way to today's 20-student team-comprised of six paid executives under a workstudy program and fourteen unpaid interns-plus several others from a variety of disciplines on campus. It plans to remain within SU as a real-world incubator of business education where students can develop professional skills for the business world through experiential and project-based service-learning.

The project has been highlighted in several Seattle media outlets such as the Seattle Times and Global Washington as well as at SU's annual Scholarship Gala. It was also documented as a case study which received the Albers Faculty-Student Research Collaboration Award in 2018 and was published in World Development Perspectives. Faculty and students presented the project at the Nobel Peace Prize Forum's Workshop on Cooperative Movements in Central and Latin America in 2017 and at the Fair Trade National Conference in 2018. It placed second out of 45 teams at SU's Harriet Stephenson Business Plan Competition, was selected as a quarterfinalist in Seattle's Social Venture Partners Competition in 2017, and competed in the Global Social Innovation Challenge in 2018.

In 2019, Café Ambiental acquired 501(c)4 status as a non-profit organization in Washington State. It continues to grow its sales throughout the Seattle area and is seeking to expand to other university campuses as well. Such an expansion will strengthen not only the project's ability to impact coffee farmers positively but also the way it conveys its message of seeking sustainably and ethically sourced products in daily life to consumers, especially through the coffee bag's farmer-focused design. Indeed, the project received the AsiaNetwork Freeman Student-Faculty Fellowship in 2018 to conduct field research in Vietnam. Six students and two faculty members thus travelled to Vietnam in the summer of 2018 to study the coffee industry there, and the project began establishing partnerships with farmers utilizing the successful collaborations with Nicaragua as a model.

To evaluate the impact of Jesuit education through service-learning projects, reflections were conducted after the trip to Nicaragua. Students led conversations and shared their thoughts with fellow students, and their comments on the project were considered as metrics for the assessment. 
I think this trip exemplifies the Jesuit mission. Returning from this trip, I feel especially empowered to succeed in business while benefitting my community and other communities. There was an element of education for all parties involved in this trip, including the SU and UCA faculty and students and the farmers, which, in my opinion, is all a Jesuit program can hope for.

The Jesuit ideal of cura personalis_care for the whole person-along with holistic personal and professional student development are woven into Café Ambiental. As a Jesuit university with a strong commitment to social justice, SU expects its students to serve communities both at home and abroad whenever there is an opportunity. Thus, while the background knowledge and skills of the students involved in the project vary widely from business and economics to environmental studies and engineering, they all share a common goal: to contribute their skills toward the promotion of social justice. Café Ambiental involves students directly in the acquisition and distribution of coffee, thereby spreading awareness of equitable value chains among the greater population on campus. The project also increases student's sensitivity to current global issues, particularly with regard to inequities in Nicaraguan coffee production and the challenges of climate change.

This student-created coffee project is thus a unique, trifold educational experience for SU and UCA students, a critical partnership of two Jesuit universities under the Central America Initiative, and a powerful example of mission engagement in the Albers School. The educational focus extends beyond the basics and encompasses experiential learning for all parties involved, one that empowers business leaders to carry out the Jesuit mission of social justice. Moreover, this model of a successful social enterprise with international collaborations has the potential to be duplicated and transferred to other Jesuit higher education institutions that have similar structures and objectives.

\section{THE NICARAGUAN COFFEE INDUSTRY}

The coffee industry in Nicaragua employs about 332,000 persons or equivalent to $15 \%$ of the country's labor force and 54\% of its agricultural sector (Bolaños, 2015). This cash crop industry contributes $14.3 \%$ of the country's agricultural GDP ${ }^{1}$ despite having the lowest average yields in Central America at about 11 bags (or $660 \mathrm{~kg}$ ) per

${ }^{1}$ From the Ministerio de Agricultura y Forestal (MAG-FOR). Data obtained in 2006. 
hectare. About $97 \%$ of the coffee producers operate on small-scale farms and are concentrated mainly in Jinotega and Matagalpa with a total cultivated area of about 126,000 hectares (Bolaños, 2015). According to Läderach et al. (2011), however, the areas suitable for coffee production in this region will decrease by $16 \%$ by 2050 , indicating substantial losses in the total cultivated area due to climate change.

The industry was analyzed using data on coffee trade statistics from the International Coffee Organization (ICO, 2015) coupled with supporting evidence from our recent field research in Penãs Blancas. The following indicators for analysis were taken from the ICO: total production by all exporting countries, domestic consumption, exportable production by all exporting countries, prices paid to growers in exporting countries, and retail prices of roasted coffee in selected importing countries. The data revealed that coffee prices have fallen severely since the early 1990s and hit their lowest dollar per pound (lb.) purchase price during the global coffee crisis from 2001 to 2003. The average real price of coffee in 1990 $(\mathrm{ICO}, 2015$; base year $=2010)$, for instance, was $\$ 1.19 / \mathrm{lb}$. before dropping to $\$ 0.59 /$ lb. in 2001 and then bouncing back to above $\$ 1.00 /$ lb. in 2006. According to the ICO, a pound of coffee in 2015 was $\$ 1.15$.

In Nicaragua, coffee growers were receiving \$0.44/lb. of coffee in 1990. During the crisis in 2002, however, the price of a pound of coffee dropped to as low as $\$ 0.30 / \mathrm{lb}$. The fall in coffee prices during this time, according to the World Bank, led to a $10 \%$ increase in poverty in the coffee producing regions of Nicaragua. Only after the crisis did prices begin to stabilize and start to rise, reaching a peak of $\$ 0.91$ / lb. in 2011. Coffee farmers in Nicaragua today receive $\$ 0.72 / \mathrm{lb}$.

According to ICO's historical data from 1990-2017, Nicaragua ranked 15th in the world in terms of coffee production, producing an average of 1,427 thousand $60 \mathrm{~kg}$ bags annually with an average annual growth rate of $9.26 \%$. The average price during the same period was $\$ 0.55 / \mathrm{lb}$. According to Gay et al. (2006: 265), "production level does not seem to respond, or it responds very slowly, to changes in prices." Coffee supply price is thus rather inelastic. Nevertheless, Figure 1 provides a scatter diagram showing a positive relationship between prices paid to coffee growers and total coffee production in Nicaragua.

Figure 2 reveals a positive trend in production, exports, and domestic consumption. Nicaragua exports almost all of its coffee-total coffee production 
and export rates grew at an annual rate of $9.26 \%$ and $9.47 \%$, respectively, between 1991-2017 (ICO, 2015). The top five destinations for Nicaraguan coffee exports from 2013-2014 were the United States, Germany, Venezuela, Belgium, and Canada. ${ }^{2}$ Domestic consumption in Nicaragua, on the other hand, is not as strong compared to other countries in the region due to a weak cultural preference for drinking coffee-Nicaraguans will only consume, on average, close to $2 \mathrm{~kg}$ of coffee per capita annually. Moreover, according to the USDA Foreign Agricultural Service (Bolaños, 2015: 3), "Nicaraguan consumers do not purchase the more expensive types of coffee. Most of the coffee consumed in Nicaragua is not suitable for export."

Figure 3, on the other hand, reveals that consumers in the United States pay very high retail prices for roasted coffee while farmers in Nicaragua receive very little compensation for what they harvest. Growers in Nicaragua receive $\$ 0.55 / \mathrm{lb}$. of coffee on average while consumers in the United States pay $\$ 3.67 / \mathrm{lb}$., making for a difference of $\$ 3.12 / \mathrm{lb}$. Where does the money go, then, if farmers are not receiving even the price for conventional coffee (a pound of washed, conventional Arabica coffee is around $\$ 1.40 / \mathrm{lb}$. on average ${ }^{3}$ ) ? The traditional trading models in the coffee industry, as it turns out, utilize eight intermediaries between the coffee grower and consumer (Miller, 2009). In terms of value chain revenue breakdown, growers receive $10 \%$, exporters $10 \%$, shippers and roasters $55 \%$, and retailers $25 \%$ (Ransom, 2006: 20).

${ }^{2}$ Information taken from the Centro de Trámites de las Exportaciones website at https:// cetrex.gob.ni/.

${ }^{3}$ Taken from the ICO website. 


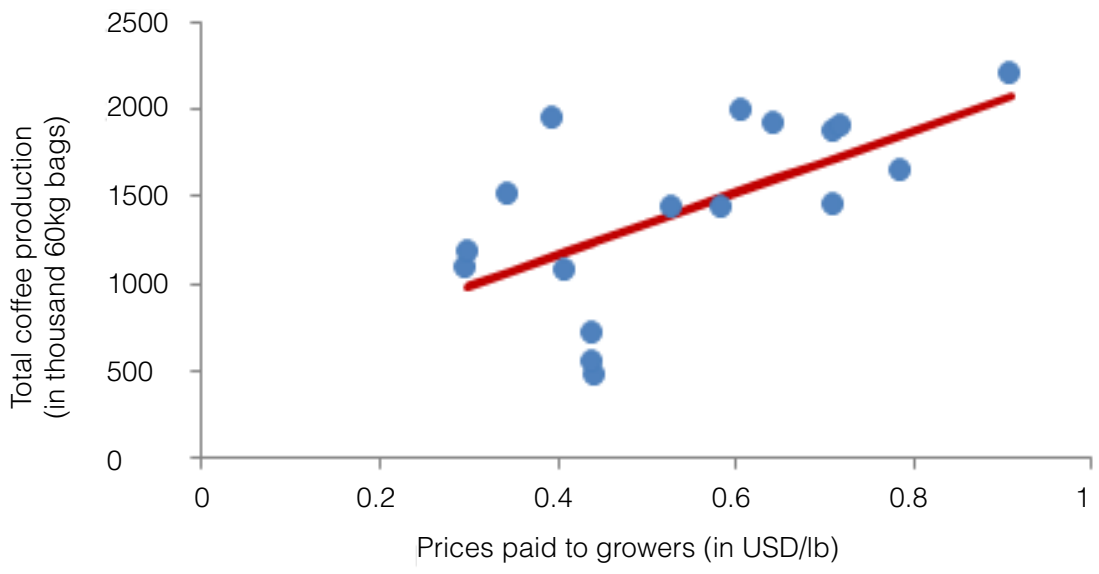

Figure 1: Prices paid to growers and total coffee production. Source: ICO (2015).

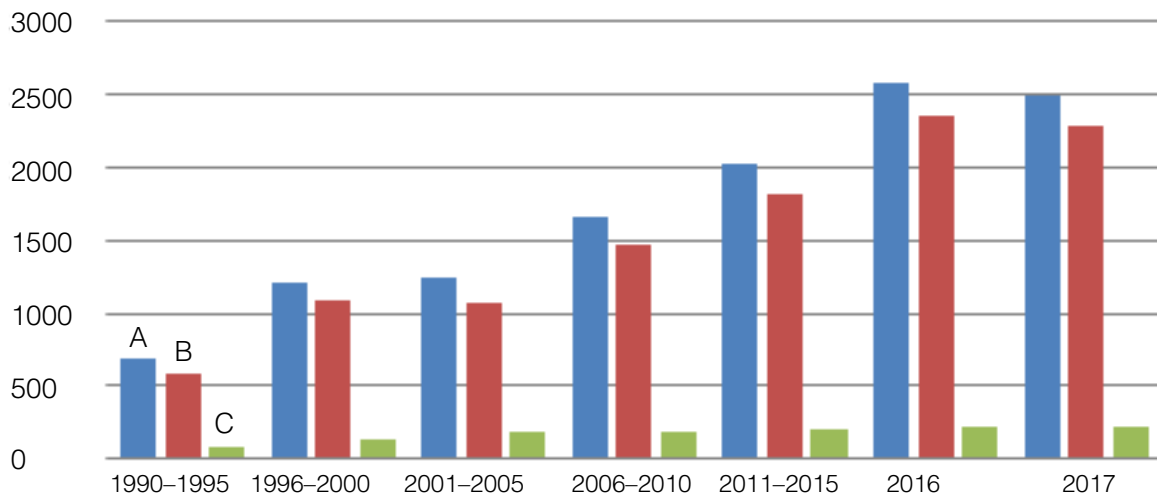

Total coffee production Exportable production Domestic consumption A B $\quad$ C

Figure 2: Total coffee production, exports, and domestic consumption. Source: ICO (2018). Unit: thousand 60kg bags. 

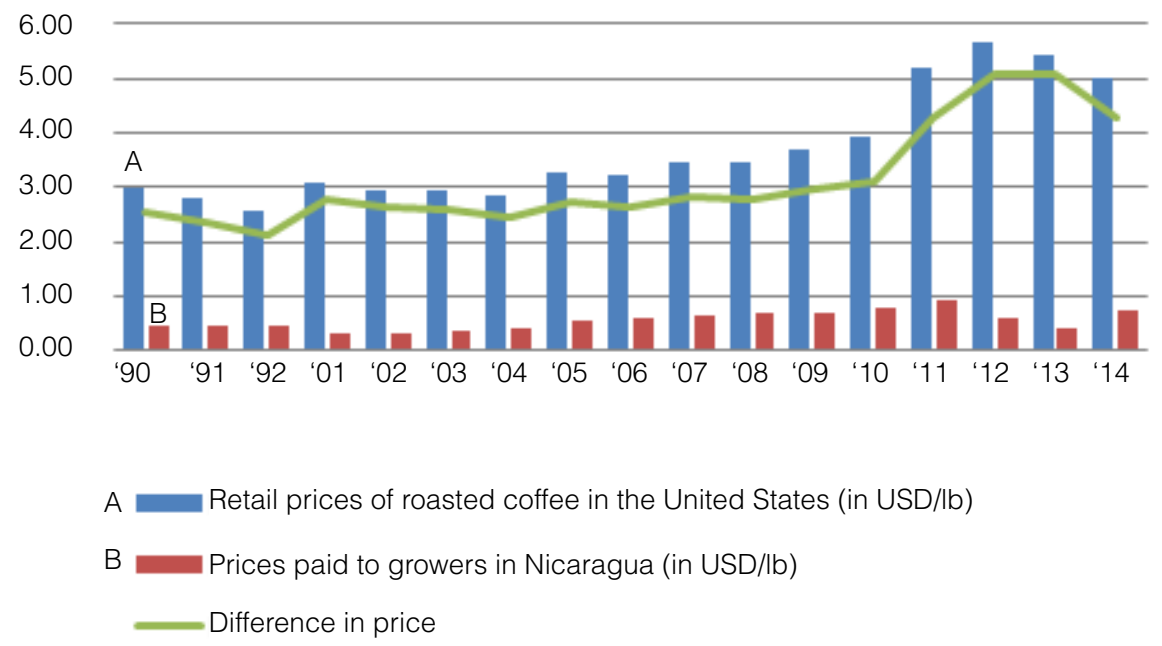

Figure 3: Coffee prices in the U.S. and Nicaragua. Source: ICO (2015).

The farmers we interviewed know clearly how inequitable the coffee supply chain is. They are aware that they are being exploited by middlemen who export their coffee. Several of them emphasized their inability to demand higher prices since the buyers would merely move on to the next farm or cooperative. As for the many farmers who expressed their desire to cut the middlemen out and work with more direct buyers, they lamented their lack of connections for establishing a direct trade partnership.

Several of the small farm owners we interviewed in Penãs Blancas also talked about the history of coffee prices and yearly fluctuations they have had to face. It began after the Nicaraguan Revolution in the 1980s which left the majority of coffee farms completely burnt. The commodity price of coffee began to decline as the farms were being rebuilt in the early 1990s, leading farmers to lose profits and making reinvestment in the farms a must. The majority of farmers were left with little personal spending money as a result. Then, when the profits were eventually not enough to support both the farms and the families running them, farmers began seeking external funding from local commercial banks, many of whom began offering small loans to farmers but at extremely high interest rates. When farmers were unable to repay the interest on the loan, the banks repossessed their land-a common scenario throughout farming communities in Nicaragua. Many farmers thus began working together and forming cooperatives to prevent financial collapse 
and repossession. These cooperatives, which comprise the majority of small farmers in Nicaragua today, give them access to exporters as well as to loans they would otherwise be too small to qualify for.

The cooperative model has noticeably improved access to capital and foreign markets for many small farmers, thereby supporting their entrance into specialty coffee markets. The price fluctuations of coffee, however, still greatly impact those who are part of cooperatives - the farmers we spoke with experienced a price drop of about $20 \%$ in 2018 alone-a significant loss-and expressed concern about the potential for another coffee crisis like the one in 2002. Their best guess for this year's price is $\$ 127 /$ quintal (1 quintal = 100lbs or $46 \mathrm{~kg}$ ) for specialty grade coffee which, to qualify as such, must receive a cupping score of around 84-87 points based on a 0-100 scale-a difficult score to achieve (SCA, n.d.). When we asked the farmers directly how much they would like to sell their coffee for, they modestly and fairly suggested $\$ 200 /$ quintal. This is equivalent to about $\$ 2.00$ per pound of coffee and just enough to keep them above the poverty line.

Since it buys directly from farmers by paying in advance those prices necessary for a sustainable wage, Café Ambiental's business model goes against the conventional practices of the coffee industry to address coffee farmers' economic and social sustainability issues. The company, which currently sources the high-quality, honey-washed Caturra variety of coffee from Gold Mountain Coffee's Matagalpa Community in Nicaragua, also purchases from across the cooperative rather than from only one or two farmers that produce exceptional coffee to prevent tension among member farms. For every $12 \mathrm{oz}$. bag sold for $\$ 12.95$ in Seattle, moreover, Café Ambiental returns $\$ 1.60$ directly to the farmers as a premium on top of the advanced payments while $\$ 3.50$ goes to a scholarship fund that supports their children (Le et al., 2017). This direct trade model thus provides farmers with peace of mind in knowing that they will receive a livable wage for the coffee they produce and mitigate their susceptibility to price fluctuations in the commodity market.

\section{THE FAIR TRADE AND COFFEE COOPERATIVE MOVEMENTS IN NICARAGUA}

As an alternative to the conventional trade model, the fair trade movement can be traced back to the late 1980s. It is based on a partnership between producers 
and traders, with a single third-party intermediary setting a price floor for buyers and ensuring that farming practices are ethically and environmentally sound (Kilpatrick, Aguirre, Forkutsa, \& Kaiser, 2015). A product certified as fair trade means that its producers and traders have met Fairtrade Standards which are designed to address the power imbalance in trading relationships, combat unstable markets, and eliminate the injustices of the conventional trade model (Kilpatrick et al., 2015).

According to Fairtrade International, whose member organizations represent the largest and most recognized fair trade system in the world, there were 445 coffee producer organizations from 2013-2014 that represented 812,500 small-scale coffee farmers across 30 countries, with $80 \%$ of all the fair trade coffee from those producer organizations coming from Latin America and the Caribbean (Kilpatrick et al., 2015: 73). More than 1.1 million hectares of land have been cultivated by fair trade coffee farmers worldwide, producing more than 549,000 metric tons of certified coffee per year (of which 34\% was also certified as organic) (Kilpatrick et al., 2015). Fair trade coffee farmers in Latin America and the Caribbean, in particular, have cultivated on plots averaging 3.1 hectares each.

The prices applied to green bean purchases worldwide (SPO) ${ }^{4}$ are $\$ 1.35 / \mathrm{lb}$. for conventional natural Arabica coffee and $\$ 1.40 / \mathrm{lb}$. for the conventional washed variety. Fair trade guarantees these minimum prices and adds a $\$ 0.20$ fair trade premium (of which at least $\$ 0.05$ is for productivity and/or quality) plus $\$ 0.30$ for an organic differential. When the conventional prices rise above the fair trade minimum, fair trade buyers will match the market price and still pay the premium to the farmers (Kilpatrick et al., 2015).

The history of the fair trade cooperative movement in Nicaragua, on the other hand, dates back to when the coffee industry was essentially destroyed in the global coffee crisis of the early 2000s. Many farmers had to abandon their farms as the international price of coffee beans collapsed. In response to this, Catholic Relief Services (CRS) in Nicaragua distributed food to coffee farmers and their families to alleviate as soon as possible the burden of the crisis and its repercussions. This emergency relief effort eventually evolved into an ongoing CRS development project that focuses on helping Nicaraguan farmers rebuild their farms and communities in the wake of the crisis. 
CRS then collaborated with both the Association for Local Agricultural Diversification and Development and Caritas Matagalpa to help farmers organize into cooperatives, provide technical training to help them improve the quality of the coffee they produce, issue guidance and support for farmers in their efforts to get their coffee certified as fair trade and organic, and connect the cooperatives to fair trade importers such as Cooperative Coffees (Miller, 2009). This new business model thereby supports the coffee farmers by helping them to improve the quality of their coffee, get their coffee certified, and reduce the number of intermediaries in the coffee value chain through direct trade.

There are now 33 producer organizations with fair trade certification in Nicaragua today (Kilpatrick et al., 2015: 159). The country once ranked fourth among the top ten in the world in terms of fair trade production capacity, with Nicaraguan farms producing 32,000 metric tons of fair trade coffee from 2013-2014 (Kilpatrick et al., 2015: 79) or about $27.5 \%$ of the total produced worldwide. Nicaragua also ranked fourth among Latin American and Caribbean countries in terms of fair trade employment with 28,200 fair trade farmers and workers or 9\% of the total in the region (Kilpatrick et al., 2015: 157) and seventh among those in the region receiving fair trade premiums from 2013-2014 with €3.28 million (Kilpatrick et al., 2015: 158 ) or $5 \%$ of the total, equivalent to $\$ 4.38$ million based on 2014 exchange rates. Each fair trade farmer or worker, in other words, received an average of about $\$ 155.17$ in premiums annually. This is a relatively small amount for helping improve the productivity, quality of coffee, and livelihoods of farmers.

Raynolds et al. (2007) argue that certifications seeking to improve ecological and social expectations are likely to be challenged increasingly by those who seek simply to uphold current standards. Certifications also have their own issues, including the extent to which coffee farmers in Nicaragua are able to benefit from being certified and having to decide which certifications to obtain. Indeed, while most of the cooperatives in Nicaragua have limited themselves until now to Fair Trade and organic certifications, the rise of new competing certification organizations such as Rainforest Alliance, Starbucks C.A.F.E. Practices, Bird-Friendly Coffee, and UTZ Certified is setting up new challenges for farmers who lack knowledge about each scheme (Valkila \& Nygren, 2009). Bacon (2005), for instance, claims that Fair Trade certified and organic are two alternative forms of specialty coffee trade and production that may offer opportunities for small-scale farmers. He argues 
that participation in organic and fair trade networks reduces the vulnerability of their livelihoods.

To understand the benefits and challenges of being certified by these sustainable certification schemes, we studied three unions of cooperatives in Penãs Blancas during our visit to Nicaragua. One of those we met with was the Cooperativa Agropecaria de Producción Guardianes del Bosque R.L. which was founded in 2003 to help farmers recover from the coffee crisis. This union is composed of six cooperatives that hope to sell coffee to specialty markets by working together and has since expanded to 68 members, 27 of whom are women. ${ }^{5}$ The members of the cooperatives immediately emphasized the need for sustainable cultivation of the land and for protecting hundreds of hectares of natural forests while simultaneously diversifying crops on the farms to ensure the health of the soil. Many farmers as such began to obtain certifications to market their coffee as truly sustainable.

While each of these certifications have had varied effects, several of the farmers agreed that these have been beneficial for their farms and extrapolated their main benefits to be technical support in and knowledge of best farming practices for developing their farms as well as knowledge of general operations management such as accounting and inventory tracking. They also noted, however, that these benefits have come from harder work and higher operational costs which have simply become the new norm throughout the region. Such certifications were originally intended to be alternative diversifying factors that would allow farms to stand out as high quality and result in higher prices for their beans. It has become instead a normal standard that all farmers must have to sell their beans to any international buyers. Indeed, several farmers viewed Fairtrade Labelling Organizations International (FLOCert) as the only economically beneficial certification.

Yet while FLOCert sets a floor price, a minimum amount the coffee should sell at, even this floor has fallen through for many of the farmers we spoke with. One of the main leaders of the union even became emotionally charged as he explained their relationship with buyers. He noted that they often reach out and agree to buy a set amount of coffee but change the conditions when the actual contracting and purchasing begin. They then insist on purchasing only half of the beans at the fair

${ }^{5}$ The majority of the union's farmers obtained the Starbucks C.A.F.E. Practices certification in 2011. Most then became UTZ certified in 2012 and Rainforest Alliance certified in 2017. The cooperatives, $40 \%$ of which produce specialty grade coffee, are audited by all these organizations. 
trade price and the other half at the conventional price which is about $\$ 0.60$ less per pound. They have grown greedy and refuse to purchase all the beans at the fair trade price even though the whole lot is fair trade and often even organic. He softly lamented that he lacked the knowledge and power as a farmer to negotiate with the buyers. Indeed, selling half the beans at the fair trade price and the other half at the conventional price is a better offer than not selling the coffee at all.

Constituted in 2016 and having obtained its official jurisdiction in 2017, the Union de Cooperativas para el Desarrollo Economico y Social, R.L., or UCODES (Union of Cooperatives for Economic and Social Development) is a relatively new union that seems to fare better compared to the one we visited previously. It consists of 12 cooperatives located in 12 communities in the municipality of La Dalia, has 320 members (199 men and 121 women), and its main objectives are to produce coffee, cocoa, and basic grains; promote environmental protection; and implement and finance projects that benefit the cooperatives. The union, which produced 3,154 quintals of coffee (certified by Rainforest Alliance and Starbucks C.A.F.E Practices) during the 2017-2018 harvest season, has the long-term goal of obtaining FLOCert and converting their farms to completely organic practices. They are getting paid direct quotes of the New York Spot coffee commodity prices plus \$15 per quintal which is different from many producers and a positive sign of price transparency.

UCODES, which has been marketing its own roasted coffee under the brand Las Brisas del Penãs Blancas since 2014, is currently looking into reducing the sale of raw coffee beans and selling roasted and branded coffee in the United States instead to add to the value chain. The union continues to support the production and promotion of coffee, cocoa, and basic grains under their own brands and receives financial support from La Fundación Felipe Rinaldi in Spain and from ODESAR (Organización para el Desarrollo Económico y Social para el Área Urbana y Rural [Organization for Economic and Social Development for the Urban and Rural Area]) in Nicaragua to fund these projects. CAIXA, a Federal Savings Bank in Brazil, also helped the cooperatives apply for credit, thereby supporting them in localizing processing and roasting for their native brand as part of their plans to open a bigger processing mill. Being able to process the coffee locally means they will depend less on the beneficio (dry mill) which is the Beneficaffora "OLAM" Grupo Fhelca Sociedad Anomina in Matagalpa, thereby decreasing their production costs. 
Another cooperative, Cooperativa Agricola de Servicios Las Brisas del Penãs Blancas, R.L (Las Brisas), received organic certification issued by MayaCert (acceptable as a USDA Organic Certificate) in Guatemala in 2018. Las Brisas has 170 producers covering a total of 394 hectares, and its farmers produce 100\% Arabica coffee of which $60 \%$ is organic and the other $40 \%$ conventional. The quality of their coffee according to one farmer is between 83-86 points. Indeed, UCODES seems to be more organized and successful despite being recently established compared to other cooperatives we have worked with in Nicaragua since 2015. There are limitations, however, to the amount of capital available to coffee farmers, thereby limiting production. Access to credit rather than their ability to sell their coffee, the leaders of the union claimed, was the biggest constraint for the development of their farms.

The certification systems that allow farmers to enter the specialty coffee markets are not perfect but they are a step in a positive direction toward achieving economic and social sustainability for many cooperatives. Ensuring that price floors are set and truly enforced is essential for limiting the corrupt practices of greedy buyers whenever they purchase coffee from farmers. Further establishing trade partnerships directly with buyers, where middlemen exporters are eliminated, is the key for farmers to receive the higher prices they deserve for their coffee. The direct trade model which Café Ambiental utilizes thus ensures that farmers always receive a livable wage despite any fluctuations in global coffee prices. By eliminating the extra costs paid to middlemen that traditional export trade models operate with, such close ties formed between farmers and consumers protect farmers from the financial instability brought on by price fluctuations in the commodity markets. Café Ambiental's model, in essence, ensures the economic stability of farmers by minimizing the steps between them and the consumer.

\section{IMPACT OF CLIMATE CHANGE ON SUSTAINABLE COFFEE PRODUCTION IN NICARAGUA}

We now shift our attention in this section to environmental sustainability. Using primary data from field research, secondary data from a previously conducted environmental analysis, and readings of bioclimatic indicators such as temperature and rainfall for the period 1990-2015 from the Climate Change Knowledge Portal ${ }^{6}$, we analyze the impact of climate change on coffee production in Nicaragua.

${ }^{6}$ See https://climateknowledgeportal.worldbank.org/. 
The average annual temperature in Nicaragua, $25.25^{\circ} \mathrm{C}$, fluctuates minimally due to the country's equatorial location and reaches a low of $24.14^{\circ} \mathrm{C}$ and a high of $26.09^{\circ} \mathrm{C}$. Research by Läderach et al. (2010 and 2011) predicts that $92 \%$ of the coffee producing regions in Nicaragua should expect a temperature increase of between $2.25-2.50^{\circ} \mathrm{C}$ by 2050 . The rise in temperature in turn will have a severe impact on coffee production, thereby putting the livelihoods of farmers at risk. Bejan et al. (2018), for instance, estimated that a 1\% rise in the average annual temperature will reduce the production of coffee by $8.75 \%$. Utilizing this estimate, we show that if the average annual temperature in Nicaragua rises from $25.25^{\circ} \mathrm{C}$ to $25.50^{\circ} \mathrm{C}$, total coffee production would be reduced from 1,427 on average to 1,302 thousand $60 \mathrm{~kg}$ bags. This is equivalent to a decrease of more than 16.5 million pounds of coffee. With the average price at $\$ 0.55 / \mathrm{lb}$, coffee growers in Nicaragua would thus lose about $\$ 9$ million per year. Figure 4 reveals a negative relationship between changes in temperature and total coffee production in Nicaragua (1990-2015) and confirms the severe impact that rising temperature has on the production of coffee.

Climate variability may also threaten future coffee production in these regions due to competition for water. According to the International Water Management Institute, rainfed agriculture accounts for $90 \%$ of how crops in Latin America receive an adequate supply of water (IWMI, 2010). The average annual rainfall in Nicaragua over the period $1990-2015$ is $195 \mathrm{~mm}$ with $287 \mathrm{~mm}$ in the wettest quarter and $103 \mathrm{~mm}$ in the driest. Läderach et al. (2010 and 2011) predict that precipitation in the coffee growing regions of Nicaragua will decrease by $60 \mathrm{~mm}$ and $7 \mathrm{~mm}$ in the wettest and driest quarters, respectively, by 2050. Figure 5 shows a negative relationship between total coffee production and changes in rainfall in Nicaragua.

Läderach et al. (2010) have also studied the impact of climate change on pests and diseases in the coffee producing regions of Mesoamerica. They find that changes in temperatures and rainfall will increase pest and disease occurrence and expand the altitudinal range in which the fungal disease coffee rust and the coffee borer beetle can survive. Their study also reveals that higher temperatures speed up the ripening of coffee barriers which results in lower cup quality and lower prices. According to the authors, moreover, given that the first showers of the rainy season prompt coffee flowering, heavy and irregular precipitation patterns may cause both coffee flowers and cherries to fall off the tree, resulting in fewer cherries and lower quality beans (Läderach et al., 2010). 


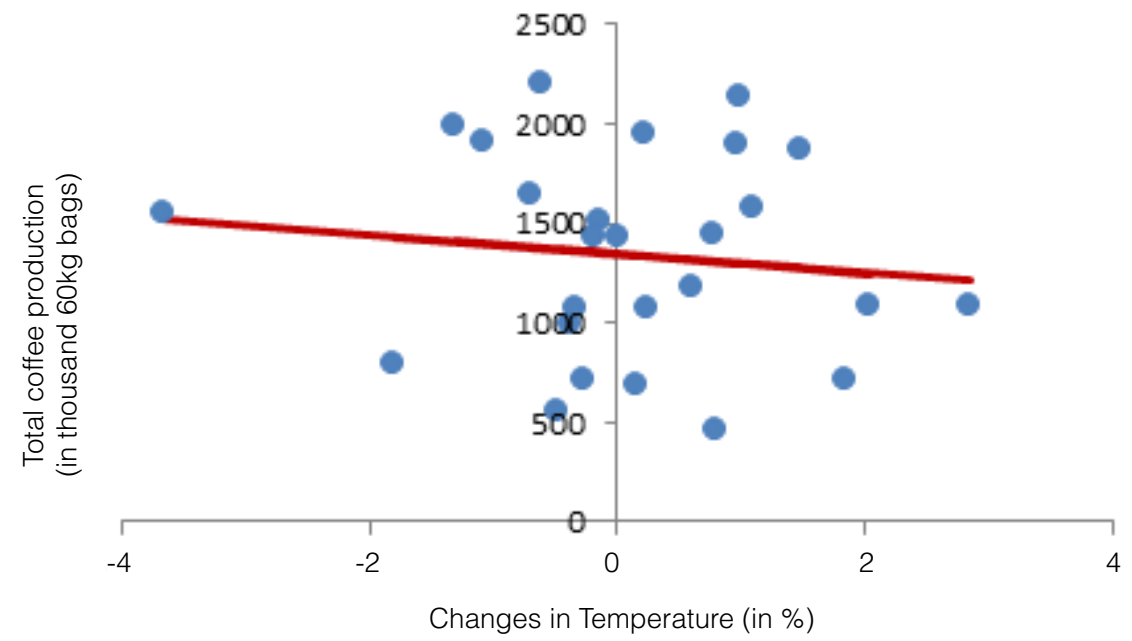

Figure 4: Total coffee production and changes in temperature. Source: ICO (2015).

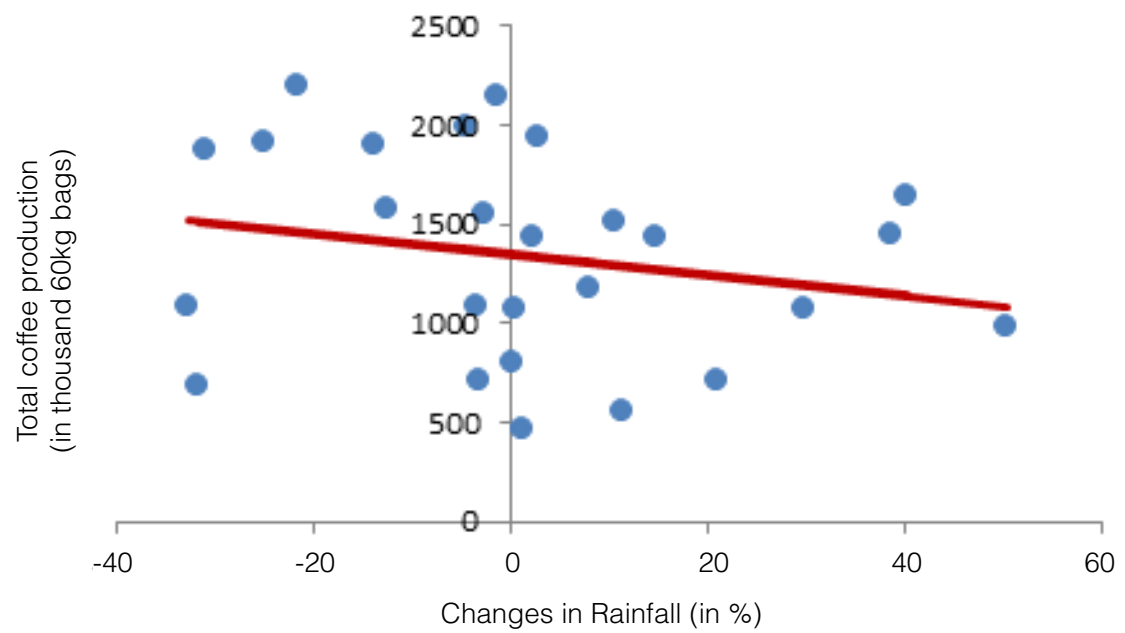

Figure 5: Total coffee production and changes in rainfall. Source: ICO (2015).

Unfortunately, such predicted changes in weather patterns have already become a reality for many of the farmers we spoke with during our field research. For Penãs Blancas, located at altitudes between 800 and 1,745 meters above sea level in the northern departments of Jinotega and Matagalpa, the rainy season extends from 
May through February and precipitation per year above an altitude of 1,000 meters ranges between 1,200 and 2,500 millimeters. Median temperatures range between $20^{\circ}$ and $24^{\circ} \mathrm{C}$.

The head of the Cooperativa Agropecaria de Producción Guardianes del Bosque R.L., who has been a part of the union since its inception in 2003, commented that he has noticed increases in overall temperature across the seasons over the past several years, thereby causing the roya fungus to spread much faster and affect far more trees than ever before. As such, even though the chemicals he currently uses to help fend off the roya fungus have been approved by Fairtrade International and been quite successful, they add a significant cost to his farming practices. He has since begun experimenting with several homemade traps and pesticides in addition to the chemicals.

Another farmer in the union who we interviewed talked about the recent changes he has noticed in the flowering season of his crops. Historically, he had been planting and preparing his 25-hectare plot in anticipation of flowering to occur mostly in the month of May. This would allow the beans to develop until October when he would then expect the harvest season to begin and last through January. Within the past two years, however, the percentage of his farm that flowers in May dropped from $50 \%$ to its current state of $10 \%$. Moreover, what used to be two main flowerings in May and June has now become a trend of seven flowerings stretching from February through May. This increased variance in flowering times that have now been spread over four months creates several new variables which farmers must learn to balance, including noting down when certain plants flower to find out when they will be ready for harvest and knowing when to begin replanting for the coming year. With plots of land spanning several kilometers, there is also a strain on cherry pickers to know when and where to begin harvesting the beans. Our findings are thus consistent with those of Läderach et al. (2010) who claim that erratic flowering and ripening cycles could require additional harvesting cycles and raise costs of production.

When asked what the biggest issue he faced recently was, the farmer quickly responded that heat and a lack of rain have greatly impacted his farm. He has begun planting other crops such as bananas for shade as well as beans and corn for supplemental income and experimenting with cacao and other shade trees to see if they can improve his soil quality. He has been using chemicals on all his land and 
does not think he can stop anytime soon due to the losses he expects to face from bugs and the roya fungus. He also noted that the bugs, specifically the coffee borer beetles, have been increasing, yet he was hopeful that the recent changes he made to diversify the crops on his land would decrease the impact the bugs and fungus were having on the coffee. He and other farmers have also been experimenting with different varietals of coffee-Bourbon, Caturra, Catimor, and Robusta-to determine the best yields and resistance to climate stress.

We confirmed what this particular farmer was talking about regarding many of these changes in weather patterns when we visited several other farmers about 100 kilometers away who were leaders of the Union de Cooperativa de Café Especial Cordillera Isabelia R.L. Three of them who were concerned specifically about the environment discussed their experience with us. When asked about some of the challenges they were facing with their farms, two of the farmers immediately responded that it was the roya fungus. Impacting farmers around the world, this fungus has been known about for a long time and various studies have proven that increases in temperature paired with heavy rainfall patterns are favorable conditions for it to thrive. All three of the farmers then talked about their attempts to improve the quality of their soil by increasing the diversity of their crops. They use these other crops, such as bananas, beans, and pineapples, which have been growing throughout their farms to help subsidize coffee growing outside of harvest season.

Historically, the harvest season used to be always dry or have minimal rainfall which is ideal for the coffee and the conditions in which to harvest the beans. The season from October 2017 to January 2018, however, was especially challenging for all three farmers who dealt with intense rainfall throughout. This posed two big challenges. First, coffee is a rather needy crop; although it requires rain during the flowering and beginning stages of growth, too much rain during the harvest season can quickly damage the coffee fruit as it is completing its development. Heavy rains also cause the soils to become too unstable for the crop's proper growth. This is because pesticide use is directly linked to soil instability as it strips the land of vital nutrients and leads to higher rates of erosion, leading many farmers to strive for organic practices. Farms with unstable soils also make access to the coffee trees difficult, especially if the harvest season is plagued with heavy rainfall. Some of the higher elevation areas quickly become unreachable, and beans can no longer be harvested once they have been left on the plant for too long. This leads 
to the second big challenge: while the farmers noted that they generally help one another during the harvest season, available labor was a rare find this past year, making the general support farmers provided one another during the harvest season unfortunately limited. This was because farmers throughout the region were scrambling to pick and collect as many beans as possible during the heavy rains before they overripened on the plants. Ultimately, such intense rainfall right at the peak of the harvest caused massive losses for all three cooperatives as well as for the union. When we asked the farmers to try and monetize how much coffee they lost, they could not put a number on it but they did note that they were unable to cover their operational costs for last year.

Our field research on environmental sustainability has thus aligned with previous studies that were done on a larger scale. The farmers we interviewed were innovative in adapting to climatic variability over the recent years by experimenting with climate stress-resistant coffee varieties, developing homemade traps and pesticides, and introducing shade trees onto their land. Given the importance of coffee to the Nicaraguan economy, however, adaptation strategies for coping with climate change should be made a priority at the national level to support the farmers. One of the most effective means of providing support, moreover, comes from encouraging and supporting direct trade partnerships like that of Café Ambiental, which provides farmers with the economic stability they need so they can invest in the sustainable development of their farms, families, and communities, thereby decreasing their susceptibility to climate fluctuations.

\section{CONCLUDING REMARKS}

The sustainable coffee framework designed in this project allowed us to gain knowledge about the coffee industry in Nicaragua, particularly from the crisis in the early 2000s to specialty markets in the present, and the current challenges under the threat of climate change which farmers face today. There is evidence projecting that climate change will reduce total coffee growing areas around the globe by as much as 50\% by 2050 (Bunn, Läderach, Rivera, \& Kirschke, 2015). This severe reduction will have a negative net impact on 25 million coffee farmers majority of whom are smallholders and on 125 million livelihoods in more than 70 countries that depend on coffee. Nicaragua depends heavily on coffee production for exports, with $17 \%$ of export earnings coming from this crop alone. Sustainable coffee is essential, 
therefore, for enabling future generations of Nicaraguan coffee farmers to continue production while preserving the environment.

Indeed, this study shows that many farmers in Nicaragua are experiencing issues with their farms' sustainability and are thus in need of strong and direct trade partnerships that can provide them with the support and consistency necessary for improving their farms. While being part of a cooperative has been beneficial for many small farms as it creates a community of support and combines resources to help one another, it has also left many farmers vulnerable to exploitation by exporters who purchase from the cooperatives at unsustainable prices. With low levels of income, farmers are left to continue unsustainable farming practices and struggle to obtain the many certifications such as Fairtrade, Rainforest Alliance, and Starbucks's C.A.F.E Practices that have now become prevalent and almost essential to selling their beans. As such, despite the fact that these certification systems do help bring small farmers from the conventional to the specialty markets, they have become more of a necessity, a norm instead of an advantage, for selling beans in the region. Nevertheless, these certifications need to be honored by exporters who can be evaluated by audits from the certification organizations to ensure that farmers are not being exploited and receiving prices lower than the set price floor. SU's sustainability studies and direct work with farmers over the past four years, moreover, have ultimately revealed that the direct trade model used by Café Ambiental is the most effective means for ensuring farmers' financial stability. This in turn allows farmers to develop the environmental sustainability of their farms even further by transitioning to organic or regenerative farming practices or investing in other equipment. Thus, an environmentally healthy farm working with a partner that provides economic stability allows for the social sustainability of the farms to flourish along with finances for improving family and community health, education, and overall livelihoods.

This project-based service-learning opportunity also went beyond mere research and provided students at SU with unparalleled business and life experiences. Kolvenbach states that graduates of Jesuit universities should have a "well-educated solidarity" with the least in society, and that "solidarity is learned through 'contact' rather than through 'concept'. When the heart is touched by direct experience, the mind may be challenged to change" (Kolvenbach, 2000: 155). We thus find that project-based service-learning has been a learning experience that enhances 
students' awareness of and sensitivity to current global issues. That awareness was established in this instance with regard to Nicaraguan coffee farmers and the coffee industry as a whole after the students worked directly within the industry. As a result, we believe that our students will approach career and professional development with a greater understanding of their impact on social justice. Our final thought is a comment from one of them:

The trip to Nicaragua to work with coffee cooperatives is a perfect example of empowering others for a just and humane world while gaining valuable professional development. This trip defines in my opinion what all trips at Seattle University should do with a service-learning component. Through engaging in solidarity and collaborating with local farmers, we not only empower those we work with but we in turn are empowered.

SU has been collaborating with our sister university to support the farmers in Nicaragua and improve the quality of their coffee for entry into the specialty markets ever since the global coffee crisis began. As such, while we do not take any credit in their endeavor, the farmers do acknowledge that both our belief in their capability and our encouragement have made a difference for them. Nevertheless, there are still many needs that have to be addressed before coffee farmers can fully capitalize on the benefits of sustainable coffee production and the specialty markets. The social enterprise created by SU students demonstrates a model that fulfills some of those needs, thereby helping to improve the lives of coffee farmers while preserving the land so future generations can grow quality coffee.

Acknowledgements: The authors are very grateful for the valuable comments and suggestions of two anonymous reviewers which helped to improve this paper considerably. This article was made possible with the support of the Global Grants program of the Office of Global Engagement, Center for Environmental Justice and Sustainability Faculty Fellowships, and Central America Initiative at Seattle University. We are grateful for the valuable contributions of the coffee farmers and cooperative managers in Penãs Blancas and La Dalia, Nicaragua to this field research. We also appreciate the collaborative efforts of our team members who joined us in this fieldwork in Nicaragua, including the following students: Hunter Adams, Sanya Cowal, Andrew Gao, Samantha Henry, and Braden Wild. Special thanks go to faculty and students from Universidad de Centro Americana in Managua, particularly to professors Carlos Vallejos, Julio Membreño, and Maria Jose Cortez as well as students 
Alfonso José Saballos Pacheco and Alejandro Martín Hernández Padilla for assisting in our field research.

\section{REFERENCES}

Bacon, C. 2005. Confronting the coffee crisis: Can fair trade, organic, and specialty coffees reduce small-scale farmer vulnerability in northern Nicaragua? World Development, 33(3): 497-511.

Bejan, V., Colaner, N., Le, Q., \& Wydick, J. 2018. Potential impacts of climate change on global production of coffee: A panel data analysis of exporting countries. Working paper, Department of Economics, Albers School of Business, Seattle University, Seattle, Washington.

Bolaños, J. 2015. Nicaragua coffee annual report. Washington, DC: USDA Foreign Agricultural Service. Available at https://gain.fas.usda.gov/Recent\%20GAIN\%20 Publications/Coffee\%20Annual_Managua_Nicaragua_6-5-2015.pdf.

Bunn, C., Läderach, P., Rivera, O. O., \& Kirschke, D. 2015. A bitter cup: Climate change profile of global production of Arabica and Robusta coffee. Climatic Change, 129(1-2): 89-101.

Francis. 2015. Laudato si': On care for our common home. Vatican City: Libreria Editrice Vaticana. Available at http://w2.vatican.va/content/francesco/en/ encyclicals/documents/papa-francesco_20150524_enciclica-laudato-si.html (accessed June 15, 2018).

Gay, C., Estrada, F., Conde, C., Eakin, H., \& Villers, L. 2006. Potential impacts of climate change on agriculture: A case of study of coffee production in Veracruz, Mexico. Climatic Change, 79(3-4): 259-288.

ICO [International Coffee Organization]. 2015. Coffee trade statistics. Available at the Statistics section of http://www.ico.org/.

IWMI [International Water Management Institute]. 2010. Managing water for rainfed agriculture. Water Issue Brief, 10: 1-4. 
Kilpatrick, K., Aguirre, J., Forkutsa, O., \& Kaiser, J. 2015. Monitoring the scope and benefits of fairtrade (7th ed.). Bonn, Germany: Fairtrade International. Available at https://www.fairtrade.net/fileadmin/user_upload/ content/2009/resources/2015-Monitoring_and_Impact_Report_web.pdf (accessed January 15, 2018).

Kolvenbach, P.-H. 2000. The service of faith and the promotion of justice in American Jesuit higher education. Santa Clara University, Oct. 6. Available at http://www.sjweb.info/documents/phk/2000santa_clara_en.pdf (accessed January 15, 2018).

Läderach, P., Haggar, J., Lau, C., Eitzinger, A., Ovalle, O., Baca, M., Jarvis, A., \& Lundy, M. 2010. Mesoamerican coffee: Building a climate change adaptation strategy. CIAT Policy Brief, No. 2: 1-4.

Läderach, P., Lundy, M., Jarvis, A., Ramirez, J., Portilla, E. P., Schepp, K., \& Eitzinger, A. 2011. Predicted impact of climate change on coffee supply chains. In W. L. Filho (Ed.), The economic, social and political elements of climate change: 703-723. Berlin/Heidelberg: Springer-Verlag.

Le, Q., Wild, B., \& Jackels, S. 2017. The case of Café Ambiental, SPC: A new business model for a Nicaraguan fair trade cooperative. World Development Perspectives, 6: $35-37$.

Miller, K. 2009. Fair trade fund support of Nicaraguan coffee farmers: A case study. Baltimore, MD: Catholic Relief Services.

Ransom, D. 2006. The no-nonsense guide to fair trade. Rotherham: New Internationalist.

Raynolds, L. T., Murray, D., \& Heller, A. 2007. Regulating sustainability in the coffee sector: A comparative analysis of third-party environmental and social certification initiatives. Agriculture and Human Values, 24(2): 147-163.

SCA [Specialty Coffee Association of America]. n.d. Protocols and best practices. Available at http://www.scaa.org/?page=resources\&d=cupping-protocols (accessed January 15, 2018). 
Spitzer, R. J. 2010. The distinctiveness of Jesuit schools. Journal of Jesuit Business Education, 1(1): 1-16.

Valkila, J., \& Nygren, A. 2009. Impacts of Fair Trade certification on coffee farmers, cooperatives, and laborers in Nicaragua. Agriculture and Human Values, 27(3): 321-333.

Quan Le has been appointed the Eva Albers Professor for 2016-2019. He is an Associate Professor of Economics and the Director of the International Business Program at Seattle University. Dr. Le teaches primarily in the areas of international economics, macroeconomics, and economic development while his research is in the areas of institutions, governance, global health, entrepreneurship, and sustainability. He has been published in Journal of International Money and Finance, International Review of Financial Analysis, Public Health, and International Journal of Entrepreneurial Behaviour \& Research. He is also a faculty advisor for the Fair Trade Colleges \& Universities Campaign and the student-created coffee project on campus.

Grace Jovanovic is a senior majoring in International Business and Environmental Studies at Seattle University. A founding member of Café Ambiental, she has traveled to both Nicaragua and Vietnam to collaborate with local farmers and assess the implications that climate change holds for the future of sustainable coffee farming. She received the AsiaNetwork Student-Faculty Fellowship in 2018 to travel to Vietnam and has co-authored several papers with faculty members on sustainable coffee. Grace is committed to advancing her knowledge in international business and environmental sustainability to pursue a professional career in the coffee industry. 